\title{
Network Benefits for Ghanaian Diaspora and Returnee Entrepreneurs
}

\author{
Sharon Doreen Mayer, Aki Harima, Jörg Freiling
}

\begin{abstract}
A B S T R A C T
Objective: The objective of this paper is to investigate how diaspora and returnee entrepreneurs use networks in the country of origin (COO) and country of residence (COR) and which benefits they gain from such networks.
\end{abstract}

Research Design \& Methods: The exploratory case study research was chosen. Faceto-face semi-structured interviews with the entrepreneurs were conducted to identify their network dynamics.

Findings: Ghanaian diaspora entrepreneurs benefit mainly from networks in the COR and Ghanaian returnee entrepreneurs from networks in the COO. These findings are not fully consistent with the assumption of previous scholars that diaspora and returnee entrepreneurs intensively use both $\mathrm{COO}$ and COR networks.

Implications \& Recommendations: The network usage of diaspora and returnee entrepreneurs varies to a large extent depending on industry, personal background and human capital. It is necessary to research more intensively the heterogeneity within diaspora entrepreneurship.

Contribution \& Value Added: This paper contributes to the development of understanding of heterogeneity in diaspora and returnee entrepreneurship. The cases present that the degree and balance of mixed embeddedness of returnee and diaspora entrepreneurs in $\mathrm{COO}$ and COR may differ to a large extent and they influence how they benefit from different type of networks in both countries.

\begin{tabular}{ll}
\hline Article type: & research paper \\
Keywords: & diaspora entrepreneurship; returnee entrepreneurship; entrepre- \\
& neurial network; network benefits
\end{tabular}

JEL codes: F22; L26; N87; O19

\section{Suggested citation:}

Mayer, S.D., Harima, A., \& Freiling, J. (2015). Network Benefits for Ghanaian Diaspora and Returnee Entrepreneurs. Entrepreneurial Business and Economics Review, 3(3), 95-122. doi: 


\section{INTRODUCTION}

It is almost a universally accepted truth worldwide that migration is a pervasive and still up-and-coming phenomenon in societies that become more transnational. In 2010, 32.5 million foreigners lived in the EU, representing $6.5 \%$ of the total EU population and $9.4 \%$ are born abroad (Vasileva, 2011). While migration is not a new phenomenon, in most recent times, rapid technology development has increased the number of migrants worldwide and changed the nature of migration. The advancement of transportation technology has reduced barriers for people to travel between countries and innovative communication technologies enable migrants to stay in touch with their home countries (Tung, 2008). The term 'diaspora' certainly helps us in understanding this transformation in its very nature. Diaspora is a certain type of migrants and refers to the people living outside of their country of origin (COO), yet maintain strong linkages with their COO (Safran, 1991; Riddle, 2008). While 'diaspora' is a concept describing a group of people, diasporan is an individual member of a diaspora.

As a result of this societal change, migration paths are more complex than before as phenomena like 'circular migration' (Newland, 2009) or return migration (Zhao, 2002; Dustmann \& Weiss, 2007) suggest. The motivation for migration has also become even more diversified than before as described in migration literature (e.g. Cohen, 2003). Therefore, it is not easy to understand diasporans' economic activities due to the inherent heterogeneity and transnational characteristics of their business, even though their entrepreneurial activities play an important role in the economy of many countries both on the micro and macro level (Aliaga-Isla \& Rialp, 2012). For these reasons, there is a strong need to understand the nature and mechanism of their economic activities.

This study takes a very early step to tackle the inherent heterogeneity of diaspora entrepreneurship, to look at diaspora entrepreneurs, diasporans who conduct entrepreneurial activities in a country of residence (COR) and returnees who have spent several years outside the $\mathrm{COO}$ and returned to become entrepreneurs. The study aims to better understand the potential impact of entrepreneur's network dynamics in both $\mathrm{COO}$ and COR on their entrepreneurial activities.

We address mainly two research gaps. First, previous research has not fully investigated the difference between diaspora entrepreneurs and returnee entrepreneurs. In fact, researches on these two topics have been done rather separately. We understand the returnee entrepreneur as a certain type of diaspora entrepreneurs, as returnee entrepreneurs are subsumed under diaspora entrepreneurs, if they have not returned to $\mathrm{COO}$ and, therefore, should not be separately investigated. Against this background, typological issues of diaspora entrepreneurship in the previous literature are discussed in the next section. In order to understand commonalities and differences between these two types of entrepreneurs, we analyze both types by paying special attention to potential differences. Besides that, the presence of returnee entrepreneurs has been considered on the macro level mainly in the context of knowledge and technology transfer (Tung, 2008; Saxenian, 2002; Wadhwa et al., 2011) and their economic contribution to their COO (Filatotchev et al., 2009; Wang, Zweig \& Lin, 2011). However, we still do not know much about their entrepreneurial activities on the micro level and their specific patterns. This study addresses this research gap by exploring the impact of networks on 
their entrepreneurial activities. For these reasons, we raise the following research questions: (i) how do diaspora and returnee entrepreneurs use their networks in their COO and COR? (ii) What are the benefits of networks in their entrepreneurial activities?

In order to respond to these research questions, we developed two case studies: one with a Ghanaian diaspora entrepreneur in Germany, who immigrated to Germany and became entrepreneur, and Ghanaian returnee entrepreneur who lived in Germany and returned to Ghana to start his own business. We intentionally chose Ghana for our empirical cases, as previous research on returnee entrepreneurship has overemphasized a few COO such as India, China and Taiwan (Saxenian, 2002; Wright et al., 2008; Murphy, 1999; Liu et al., 2010). While these countries have probably benefited from resources and contributions of returnee entrepreneurs more than other countries, this phenomenon is also relevant to other countries. Moreover, we also deliberately selected entrepreneurs in the non-technology industry, as earlier literature focuses mainly on returning experts of the information and communication technology industry (Saxenian, 2002; Wright et al., 2008; Liu et al., 2010; Kenney, Breznitz \& Murphree, 2013). Semistructured interviews have been conducted and the collected data was structured and interpreted in a rather explorative way to get first impressions about the role of networks in their entrepreneurial activities.

The structure of this study is as follows. First, we present the current research status of diaspora entrepreneurship and returnee entrepreneurship as well as entrepreneurial networks. Second, we briefly develop our assumption in terms of the potential roles of networks in entrepreneurial activities of diaspora and returnee entrepreneurs. Third, the empirical approach is explained. Fourth, we present two cases. After that, we discuss findings in the light of the research questions and present our contributions as well as limitations.

\section{LITERATURE REVIEW}

\section{Diaspora Entrepreneurship and Returnee Entrepreneurship}

By now, 'diaspora' has often been treated as a synonym for the Jewish diaspora or other classical diaspora groups such as Armenians and Greeks by some dictionaries and researchers (Sheffer, 2003). Most recently, this term is used far beyond these groups. 'Diaspora' is understood as a more universal concept which describes "ethnic minority groups of migrant origins residing and acting in host countries but maintaining strong sentimental and material links with their countries of origin" (Sheffer, 1986, p. 3).According to Safran (1991), the concept of diaspora is applied to groups of people being dispersed from their original homeland who are characterized by shared collective memory, vision, or myth about their COO. Diasporan refers to a member of diaspora. Diasporans have therefore a strong emotional connection to their COO (Safran, 1991). More recently, Brubaker (2005, p. 5-7) regards diasporans, based on Sheffer's (2003) definition, as people who meet the criteria of dispersion, homeland orientation and boundary maintenance.

Diasporans' economic engagement plays an important role in the world economy (Aliaga-Isla \& Rialp, 2012). Statistics show that the remittances from diasporans play an essential role in the economy of COOs. In 2014, the total remittance flow was projected to reach 435 billion USD, which is 5\% higher compared to 2013 (World Bank, 2014:3). 
Among different types of economic engagement of diasporans, their entrepreneurial activities have attracted increasing attention from researchers as a form of alternative economic adoptions to becoming an employee of existing firms(Portes et al., 2002; Eraydin et al., 2010). Diasporans often become entrepreneurs based on different motivations. Some are more necessity-driven by difficulties in finding a job in the COR, while others recognize entrepreneurial opportunities (Chrysostome, 2010) they feel attracted by.Diaspora entrepreneurs often address unique opportunities due to their 'mixed embeddedness' in the COO and COR (Kloosterman, van der Leun \& Rath, 1999.). Mixed embeddedness describes the integration of immigrant entrepreneurs who are involved not only in social networks of immigrants and $\mathrm{COO}$, but also in the socio-economic and politico-institutional environment of the COR (Kloosterman \& Rath, 2002). Mixed embeddedness also allows them to access diaspora resources including diaspora networks (Kuznetsov, 2006), cognitive diversity (Clydesdale, 2008) and intercultural competencies (Westwood et al., 2000).

Research on diaspora entrepreneurship is still in an infant stage. There is multitude of similar and related concepts to entrepreneurial activities of diasporans such as ethnic (minority) entrepreneurship (Zhou, 2004; Volery, 2007; Clark \& Drinkwater, 2010), immigrant entrepreneurship (Rath \& Kloosterman, 2000; Light, Bhachu \& Karageorgis, 1993; Piperopoulos, 2010), transnational diaspora entrepreneurship (Nkongolo-Bakenda \& Chrysostome, 2013; Kyle, 1999; Riddle et al., 2010) and returnee entrepreneurship (Wright et al., 2008; Filatotchev et al., 2009; Liu et al., 2010; Kenney, Breznitz \& Murphree, 2013). While there have been some attempts to develop a typology of immigrants' business activities such as the ones of Landolt, Autler and Baires (1999) and Drori, Honig and Wright (2009), current research still suffers from a lack of common definitions. To avoid terminological confusions, we clarify our understanding of different conceptual categories of diaspora entrepreneurship.

Ethnic (minority) entrepreneurship and immigrant entrepreneurship are often used as synonyms and are defined as 'a set of connections and regular patterns of interaction among people sharing common national background or migration experiences' (Waldinger, Aldrich \& Ward, 1990b, p. 3). This concept originates from the USA where migrants have been over-presented in the small business sector (Barret et al., 1996). According to Volery (2007, p. 31), markets with dominant ethnic entrepreneurs are characterized by 'low barriers of entry in terms of required capital and educational qualifications, small-scale production, high labor-intensity and low added value, while cutthroat competition reigns.' The motivation to become self-employed of ethnic entrepreneurs has been described mainly as necessity-driven (Volery, 2007). The concept has gradually evolved from the original stereotype of ethnic small business run by low skilled migrants towards more diversified sectors.

While the concept of ethnic and immigrant entrepreneurship focuses on the social and political positions of migrants in their host countries, the one of diaspora entrepreneurship is unique in regard of valuing diasporic characteristics such as mixed embeddedness (Kloosterman, van der Leun \& Rath, 1999) and emotional connections to COO (Safran, 1991). Therefore, diaspora entrepreneurship is not limited to the first generation as ethnic and immigrant entrepreneurs but covers also the second and third generation of migrants. 
Similar to the concept of diaspora entrepreneurship, there is a concept called diaspora transnational (international) entrepreneurship (Elo \& Freiling, 2015; NkongoloBakenda \& Chrysostome, 2013; Riddle et al., 2010; Chen \& Tan, 2009). Transnational entrepreneurs are defined as foreign born, self-employed persons who engage in entrepreneurial activities in which they need to travel abroad frequently and entrepreneurs' critical resources are located mainly in their COO (Portes, Guarnizo, \& Haller, 2002). As visible in this definition, this concept focuses rather on transnationalism of entrepreneurial activities.

In this paper, we understand diaspora entrepreneurship based on their characteristics and emotional homeland connection without the transnational dimension applied to the above-mentioned concept of diaspora transnational entrepreneurship. Networks of diaspora transnational entrepreneurs are transnational due to the nature of their business. However, diaspora entrepreneurs without transnational economic activities may also have networks both in $\mathrm{COO}$ and COR due to their mixed embeddedness. For this reason, we intentionally focus on diaspora entrepreneurship as well as returnee entrepreneurship, both without the strong focus on transnational business nature.

Returnee entrepreneurship is a sub-type of diaspora entrepreneurship according to Drori, Honig and Wright(2009). In this paper, we define returnee entrepreneurs as individuals who gathered vocational or educational experiences as diasporans in developed countries before returning to their COOs to establish their own businesses. Since they belong to diasporas, they possess comparable characteristics, including mixed embeddedness and homeland orientation and resources, to diaspora entrepreneurs. Returnee entrepreneurs have considerable influence on the economy of the $\mathrm{COO}$, especially from the perspective of knowledge transfer. Migrants have been associated with a loss of knowledge and skill to the COO, often perceived as a 'brain drain' (Bhagwati \& Hamada, 1974, pp. 19-41). However, when these migrants return to their COO by circular migration (Venturini, 2008), they also bring back their human capital and the COO experience, which can be described as a 'brain gain' (Riddle, 2008). Saxenian (2005) retitles this phenomenon as a 'brain circulation', which has positive impacts on both $\mathrm{COO}$ and COR.

Drori, Honig and Wright (2009, p. 1006) define them as "scientist and engineers returning to their home country to start a venture after several years of business experience in other (developed) countries". In a similar vein, Liu et al. (2010, p. 1184) define returnees as 'scientists and engineers or students who trained or studied in OECD countries and returned to their native countries to start up a new venture or work for a local company'. As indicated in their definitions, most of the previous research in this field focuses on highly skilled returnee entrepreneurs especially in the high-tech industry from China, India and Taiwan. Their contribution to the establishment of high-tech firms and science parks in their COOs has been the focus of attention (Wright et al., 2008; Dai \& Liu; 2009; Filatochev et al., 2009; Liu et al., 2010; Kenney, Breznitz \& Murphree, 2013).

However, research beyond those countries and on other industries is limited, even though the phenomenon of returnee entrepreneurs is relevant far beyond. African nations, such as Ghana, are not well considered (except cf. Black et al., 2003) although playing a role in this context. In a similar vein, a returnee does not necessarily have to be a highly skilled expert to contribute to the development of his COO. Less skilled diasporans returning to their $\mathrm{COO}$ and becoming entrepreneurs also have an important influ- 
ence on the local economy, as they bring back human capital which can be useful to the COO (Elo, 2014). They improve their human capital through their experience in a new cultural and societal environment in COR, adapting to a new culture, learning a different language and gaining knowledge in a certain industry.

According to Liu and associates (2010), returnee entrepreneurs possess unique characteristics that differentiate them from non-returnee entrepreneurs: (i) idiosyncratic human capital resources; (ii) specific social capital. First, they argue that high-skilled returnee entrepreneurs have an access to broader pools of human capital resources due to acquired academic knowledge through general education, scientific and technical training, and practical business skills. While their arguments are obviously developed for the returnees with high skills, this can be also applied to the low-skilled returnees. Even when they do not acquire academic knowledge from higher educational institutes, diasporans gather unique experience as well as knowledge through education, vocation and even private life in CORs. Through being embedded in the COR society, diasporans learn various things including language, culture, values, technology, markets and even institutions (Riddle \& Brinkerhoff, 2011). Such experience during the time in the COR enriched human capital of returnee entrepreneurs. Second, Liu and associates (2010) discuss that unique social capital of returnees may develop which involves both relational and structural resources (Cooper \& Yin, 2005). Since this justification does not exclude low-skilled returnees, low-skilled returnees are assumed to possess such social capital, which eventually has an impact on their business.

Considering the discussion above, this paper focuses on returnee entrepreneurs in Ghana in non-skill intensive industry for the purpose of extending the existing literature and discovering new insights from different country context. In order to research returnee entrepreneurship in a broader context, we extend the definition of Drori, Honig \& Wright(2009) and define returnee entrepreneurs as diasporans leaving their COO for educational, labor and/or business opportunities, returning after several years to their COO to start a venture.

\section{Network Theory in Entrepreneurship}

According to Hoang and Antoncic (2003), who made one of the major contributions in network research in the context of entrepreneurship by their literature review, research on networks within the field of entrepreneurship emerged as an important stream in the late 1980's. Starting with Aldrich and Zimmer (1986) who argued that the embeddedness of entrepreneurs in social networks plays a critical role in the entrepreneurial process, a number of scholars agree that networks have a considerable importance to entrepreneurship (Davidsson \& Honig, 2003; Hoang \& Antoncic, 2003; Shane \& Cable, 2002; Slotte-Kock \& Coviello, 2009).

Based on their extensive literature review, Hoang and Antoncic (2003) identified three main research areas: (i) the nature of the content that is exchanged between actors; (ii) governance mechanisms in relationships; and (iii) the network structure created by the cross-cutting relationships between actors. Slotte-Koch \& Coviello (2009) additionally considered the process of network within the field of entrepreneurship.

The research on network content is highly related to network benefits. Researchers have argued that the role of networks for entrepreneurs is to access both tangible and intangible resources. A few studies focused on tangible resources such as capital (Light, 
1984; Zimmer \& Aldrich, 1987; Chen \& Tan, 2009). Byusing networks, entrepreneurs gain access to financial capital including financing by angel investors and venture capitalists (Hoang \& Yi, 2015).

Previous research put stronger emphasis on intangible resources such as emotional support, which reduces entrepreneurs' perception of risk (Brüderl \& Preisendörfer, 1998; Gimeno et al., 1997). Another key benefit of networks for entrepreneurs is the access to different information. Freeman (1999) argues that social ties to various actors may provide entrepreneurs with market information and the access to key talent. A number of studies confirmed that networks also help entrepreneurs to recognize entrepreneurial opportunities (Joannisson, 1990; Birley, 1985; Ozgen \& Baron, 2007).

Such intangible network benefits originate from entrepreneurial role models within networks. For instance, Klyver, Hindle \& Meyer, 2008) found that personal ties to entrepreneurs offer an entrepreneurial role model, which increases the probability of becoming an entrepreneur. The importance of the presence of entrepreneurial role models within networks are confirmed by other researchers as well (Hoang and Gimeno, 2010; Nocolaou \& Birley, 2003).

A network has different dimensions. According to O'Donnell et al. (2002), one of the most common dimensions used for entrepreneurship research is formal and informal (social) network (Brown \& Butler, 1993). The inter-organizational network describes all formal linkages, the contacts new firms are embedded in, and that define "the opportunities potentially available" and related to business organizations and maybe even nonprofit organizations (Uzzi, 1996). In contrast, social networks rest on personal, not organizational relationships with the informal contacts entrepreneurs have - such as family, kinship and friends.

When investigating networks in entrepreneurship, researchers should be aware of the difference in terms of the nature of network such as size, centrality and density (Brüderl \& Preisendörfer, 1996). Size and centrality display the amount of resources an entrepreneur can attain from a certain network. The density, in contrast, describes the extent to which an entrepreneur can reach new information (Hoang \& Antoncic, 2003). Granovetter (1973) highlighted the role of weak ties and argues that entrepreneurs can benefit from ties that are located outside the regular contacts (weak ties). Weak ties are loose relationships between individuals which can extend networks by linking individuals and organizations. These weak ties can also function to bridge the so-called "structural holes" (Burt, 1992), which means that entrepreneurs can benefit from developing ties that bridge unconnected actors. In contrast, Coleman (1990) develops the 'network closure argument' which states that networks of strong ties enable information transfer because they prove commitment, understanding and trust. Following this reasoning, Arenius and De Clercq (2005) suggest that a 'high level of cohesion', a network of many strong ties, is effective in terms of knowledge transfer.

There are several benefits entrepreneurs can gain from their networks. One of the main benefits is an access to new information and knowledge through network, which supports their opportunity recognition (Arenius \& De Clercq, 2005). Second, networks with (potential) customers and suppliers are useful to entrepreneurs in order to build reputation as well as to gain market information (Brown \& Butler, 1993; Shane \& Cable, 2002). Third, entrepreneurs can receive informal financial capital from network partici- 
pants. Besides the economic support, networks especially with family can offer emotional support, motivation as well as unpaid labor (Brüderl \& Preisendörfer, 1996).

While a few studies have been conducted on this topic in this context (Smans et al., 2014; Harima, 2014; Zhoug \& Liu, 2015; Mustafa \& Chen, 2010), the way how diaspora and returnee entrepreneurs use their network is still underexplored.On one side, diasporans and returnees are assumed to have an access to extensive networks both inCOOs and CORs due to their mixed embeddedness. There are, however, some studies which argue that they lose their social capital due to long absence in their COOs and therefore do not gain significant benefits from networks for their entrepreneurial activities (Wahba \& Zenou, 2011).

Previous research shows different results in terms of network structure of returnee entrepreneurs. Farquharson and Pruthi (2015) find that Chinese returnee entrepreneurs greatly rely on strong ties with family and close friends back in China during the process of establishing a business and weak ties with governmental agencies in COR. There is, however, a contradictory study that claims that returnee entrepreneurs work more closely with the Chinese government and the role of friends in China is more important to local entrepreneurs than returnees (Vanhonacker, Zweig \& Chung, 2005).

In the next section, we will briefly discuss the possible impact of different types of networks on diaspora and returnee entrepreneurs based on findings of previous research.

\section{Current Research Status on Ghanaian Diaspora and Returnee Entrepreneurs}

To understand the overall constellation of Ghanaian diaspora and returnee entrepreneurs, we start with general information about migration between Ghana and Germany. Ghana is one of the representative nations of diasporans and migrants living in Germany. According to statistics, Ghanaians are the largest group of migrants from Sub-Saharan Africa in Germany (Statistisches Bundesamt, 2013). Furthermore, Ghana's economy has been rapidly growing in the last years, which attracts overseas Ghanaians to return to their COO eventually to become returnee entrepreneurs.

Ghanaian diasporans have not attracted much research attention, especially in the context of entrepreneurship. There are only a few studies conducted on Ghanaian returnees, but mostly on the macro level (Nieswand, 2009; Black, King \& Tiemoko, 2003; Ammassari, 2004; Black \& Castaldo, 2009). We still know little about how Ghanaian diaspora and returnee entrepreneurs benefit from their networks. However, some former research contributions illuminate the situation where Ghanaian diasporans are placed. Previous research on Ghanaian returnees has mainly focused on the role of capital transfers (Black \& Castaldo, 2009) and on home country contributions of high-skilled returnees (Ammassari, 2004; Avle, 2014). For instance, Avle (2014) finds that the main motivation of returnee entrepreneurs to return to Ghana is to support the development of their home country, and secondarily to benefit from economic opportunities. These findings support the findings by Riddle (2008) that returnees have strong linkages and emotional ties to the COO during the time abroad and want to support the development of their homelands with their human, social and financial capital they have gained abroad. 


\section{Networks of Ghanaian Diaspora and Returnee Entrepreneurs}

In this part, we discuss from which networks Ghanaian diaspora entrepreneurs in Germany and Ghanaian returnee entrepreneurs who got back from Germany can possibly benefit in their economic activities- and how, based on the literature. The aim of this section is not to develop concrete research propositions, but rather developing our understanding of overall constellations of such entrepreneurs including country-specific conditions and environment, which is required to explore their network dynamics.

Due to the mixed embeddedness (Kloosterman, van der Leun \& Rath, 1999), Ghanaian diaspora and returnee entrepreneurs are assumed to have different types of networks in Ghana and Germany. When they are first generation migrants, they are likely to still have strong ties with their family and relatives as well as friends and acquaintances in Ghana. As indicated by Wahba and Zenou (2011), they may have lost some of weak ties during the time they spent abroad. Additionally, it may also be the case that they have some formal networks such as business relationships with former employers, colleagues and some contacts with companies (suppliers or customers) when they have working experience in their $\mathrm{COO}$ prior to their migration to Germany. Particularly for returnee entrepreneurs, they may have some additional networks established after their return such as community with other returnees.

Many years of experience in Germany allows Ghanaian diaspora and returnee entrepreneurs to establish extensive networks there as well. They are assumed to have established informal networks such as family and relatives as well as friends and acquaintances and formal networks through vocational experience in Germany. Additionally, they are often in regular contact with the 'diaspora community' (diaspora network) in Germany. Diaspora networks can both be informal and formal. Chrysostome and Arcand (2009) also find that the Ghanaian ethnic market niche, the ethnic social network, the ethnic labor and the ethnic emotional support are significant benefits for Ghanaian diasporans. Network types of diaspora and returnee entrepreneurs are visualized in Figure 1 and Figure 2.

As for network benefits, Ghanaian diaspora and returnee entrepreneurs are assumed to be able to gain the following benefits from networks: (i) access to information and knowledge, (ii) access to customers and suppliers, (iii) reputation, (iv) access to financial support, (v) access to human resources, and (vi) emotional and motivational support.

First, they are assumed to have easier access to information and knowledge about institutions, cultural norms as well as markets of both COO and COR through their networks (Harima, 2014; Vemuri, 2014). Being familiar with a certain institutional environment and having information on the target market reduce the difficulties in operating a business, and therefore may have a positive impact on their entrepreneurial activities (Zaheer, 1995). Second, networks allow them to access potential customers in both countries. Auster and Aldrich (1984) argue that diaspora entrepreneurs often target coethnic customers. For instance, a Ghanaian 'Afro-Shop' in Germany, which sells Ghanaian food, products, and traditional clothing, is an example of such ethnic market niches. Third, a network can build up a sound reputation of entrepreneurs by recommendations as suggested by Shane and Cable (2002). Fourth, both diaspora and returnee entrepre- 
neurs may have an access to financial resources of co-ethnics (cf. Light, 1984; Zimmer \& Aldrich, 1987). Due to diasporans' emotional connection to the COO, diasporans often invest

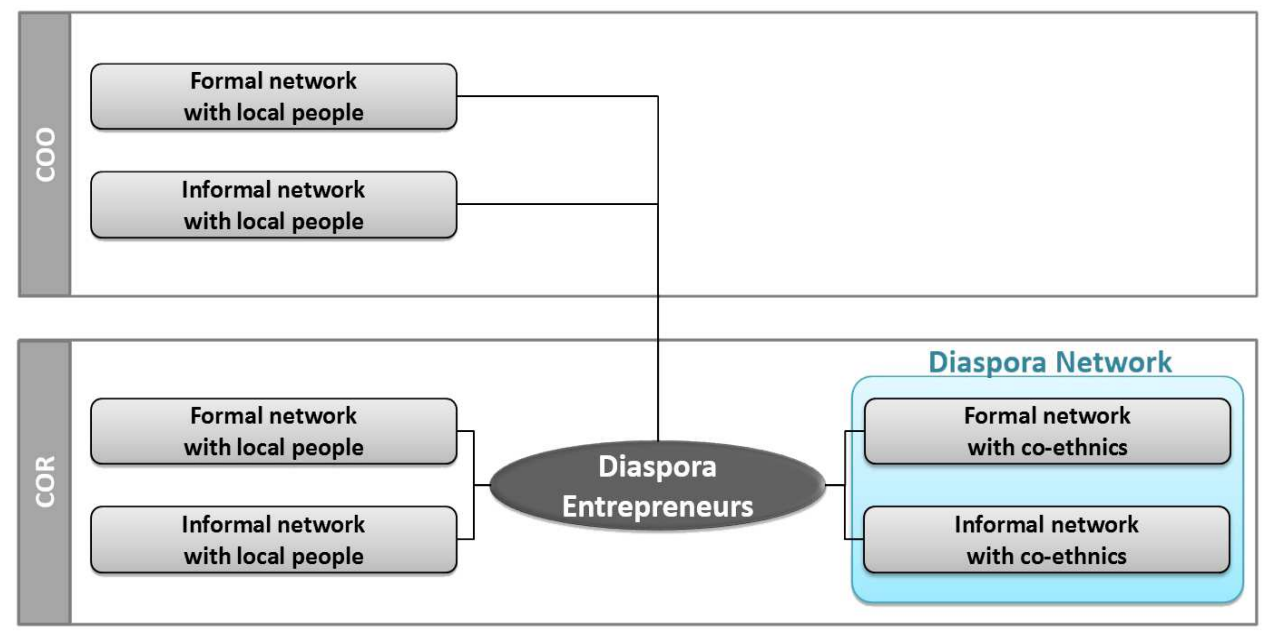

Figure 1. Networks of Diaspora Entrepreneurs

Source: own elaboration.

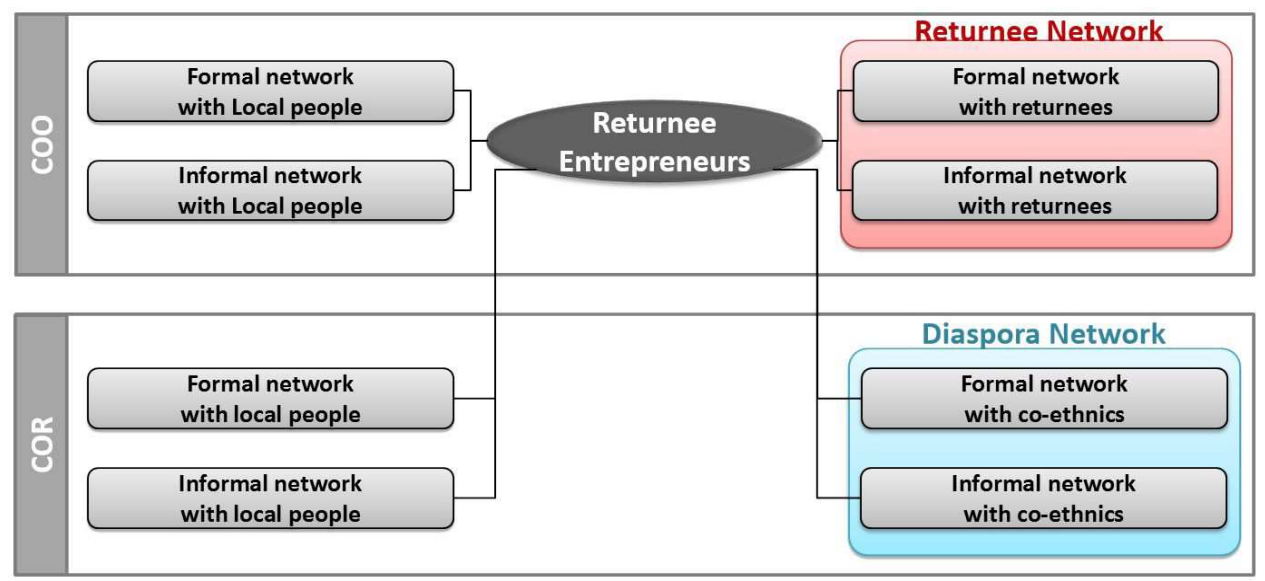

Figure 2. Networks of Returnee Entrepreneurs

Source: own elaboration.

in businesses of co-ethnics (Nielsen \& Riddle, 2009; Light, Bhachu \& Karageorgis, 1993; Gillespie et al., 1999). Additionally, there are many cases of diaspora entrepreneurs who finance their business through financial support from family members (Aldrich \& Cliff, 2003). Fifth, especially diaspora networks can offer low-wage labor as addressed by many researchers (Evans, 1989; Aldrich, Waldinger \& Ward, 1990a; Basu \& Goswani, 1999; Altinay \& Altinay, 2008). Such people may also offer skills specific to the ethnic groups. For the reason of solidarity with co-ethnics and/or difficulties in finding a job 
outside of ethnic market niche, co-ethnics often work for low wages (Chrysostome \& Arcand, 2009). As insufficient financial resource is one of the most frequently named reasons for entrepreneurial failure, reducing labor costs is assumed to be a substantial benefit to entrepreneurs. The last possible benefit is emotional and motivational support. Networks offer, for instance, successful entrepreneurial role models (Bosma et al., 2012). Furthermore, patriotic sentiment of returnee entrepreneurs is assumed to be positively related to motivation maintenance toward entrepreneurial activities.

\section{MATERIAL AND METHODS}

The aim of this study is to explore network benefits of Ghanaian diaspora and returnee entrepreneurship by answering the following two research questions: (i) how do diaspora and returnee entrepreneurs use their networks in COO and COR? (ii) What are the benefits of networks in their entrepreneurial activities?

To respond to these research questions, we employ an explorative research design that takes into account the rather early state of research in connection with the considerable complexity of the topic. Prior research informs us about first insights but does not provide causal relationships that could undergo first empirical checks. Against this background, we are in an intermediate state that could advance our knowledge by collecting more data, trying to identify structures based on a growing body of data and preparing causality checks at a later point in time. Description of the relevant phenomena and first interpretations stand at the forefront of this step of research and do not call for a case sampling logic that is needed for dealing with already formulated research propositions for the sake of pattern matching in the Hayekian (Hayek, 1967) sense (cf. Yin, 2013; Eisenhardt, 1989). Whereas, for first reality checks of causalities, four or even more cases are needed (Yin, 2013; Eisenhardt, 1989), this kind of 'early exploration' intends to benefit from understanding one case or a smaller number is useful for the first understanding (Lervik, 2011). Against this background, the question is whether to start data structuring and interpretation based on a single case or a situation with first comparisons. To gain first impressions beyond an often quite subjective single case, we chose the latter option to have the opportunity to contrast the cases without claiming for conducting a real cross-case analysis that would be more appropriate in later steps of the research process.

As for case selection, diaspora and returnee entrepreneurs are characterized by their social and cultural embeddedness in multiple contexts. Therefore, their network dynamics are highly situational and specific to the context. This study does not intend to find universal patterns in terms of network benefits, but to develop our contextual understanding of the role of networks in Ghanaian diaspora and returnee entrepreneurship.

Two cases have been carefully selected: one case with a Ghanaian diaspora entrepreneur (Entrepreneur A) and the other with Ghanaian returnee entrepreneur (Entrepreneur B). Entrepreneur A and entrepreneur B have similar backgrounds in terms of age, migration experience, and timing of starting a business. Choosing cases with comparable backgrounds allows us to control extraneous variations (Eisenhardt, 1989). The purpose is not to make a direct comparison, but to highlight situational differences between diaspora and returnee entrepreneurs (Stake, 2010). Entrepreneur B has taken over a business of his mother and became the owner of the company. Although he did 
not establish the company from the scratch, he drastically renewed a number of aspects of this business, which results in transforming the original company into a new one. Insofar, B can be regarded as an entrepreneur for this study. Table 1 comprises an overview of characteristics of entrepreneur A and B.

Table 1. Profiles of Entrepreneur A and Entrepreneur B

\begin{tabular}{|c|c|c|c|c|c|c|c|}
\hline 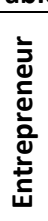 & & 品 & 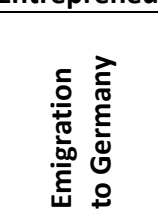 & 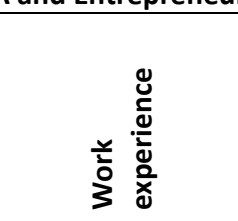 & 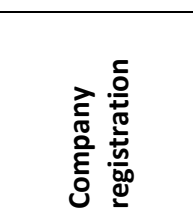 & 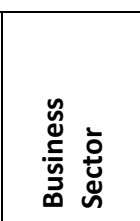 & 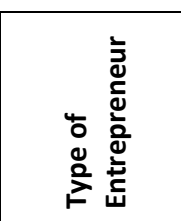 \\
\hline A & Male & $20-55$ & 1980-1985 & $\begin{array}{c}\text { 10-20 years craft } \\
\text { business }\end{array}$ & $\begin{array}{c}\text { 2000-2010 in } \\
\text { Ghana }\end{array}$ & Industrial & \begin{tabular}{|c|} 
Diaspora \\
entrepreneur
\end{tabular} \\
\hline B & Male & $50-55$ & 1980-1985 & $\begin{array}{c}10-20 \text { years craft } \\
\text { business }\end{array}$ & $\begin{array}{l}\text { 2000-2010 in } \\
\text { Ghana }\end{array}$ & Service & \begin{tabular}{|c|} 
Returnee \\
entrepreneur
\end{tabular} \\
\hline
\end{tabular}

Source: own elaboration.

Ghana has been chosen as a target country for this study. Ghanaian migrants show strong presence in Germany. In 2013, 24790 persons with Ghanaian citizenship were registered in Germany (Statistisches Bundesamt, 2013), which is the largest number of migrants from Sub-Saharan Africa in Germany. The overall number of Ghanaian diasporans is assumed to be higher than official statistics as the number from Statistisches Bundesamt does not cover all of the Ghanaian diaspora in Germany and neglects, e.g., second- and third-generation Ghanaian migrants (Federal Ministry of Economic Cooperation and Development, 2009, p. 7).

Face-to-face semi-structured in-depth interviews were conducted as amethod of collecting emic knowledge of entrepreneurs in February 2015. The interview consists of three parts. The first part focuses on personal information about the interviewee and his company. The second part seeks information about the interviewee's career progression in the past. The third part explicitly deals with network benefits. For the last part, interview guideline was developed based on our assumption regarding networks of Ghanaian diaspora and returnee entrepreneurs described above. In the interview, mostly openended questions were used in order "to have the participant reconstruct his or her experience within the topic under study" (Seidman, 2005, p. 15).

The interviews took approximately 45 minutes and were recorded and transcribed in original language (German). Quotations used in this paper have been analogously translated by the authors. The transcripts of the interviews are analyzed in line with our assumption above. For the sake of investigator triangulation (Denzin, 1970), two authors analyzed the transcribed interview text separately in line with a priori structure developed in the previous section. Moreover, for triangulation purposes, the research team collected additional data wherever possible (e.g. field observations, documents).

\section{Ghanaian Diaspora in Germany}

Before presenting the findings, the historical background of Ghanaian diaspora is briefly outlined. This information is helpful to understand special cultural and societal settings of Ghanaian diaspora and returnee entrepreneurs. There have been many reasons for 
Ghanaians to migrate to other countries: in the first half of the 20th century, Ghanaians mostly migrated to English-speaking nations for educational or business purpose. Since the mid-1960s, political and social crises forced a number of Ghanaians to emigrate. The United Kingdom, Germany, and the Netherlands became primary destinations. In the 1990s, the motive of having a better life without poverty and supporting the family back home by remittances became major reasons for migration (Federal Ministry for Economic Cooperation and Development, 2009, p. 7). Total remittances to Ghana in 2010 reached 119 million USD, 8 million USD out of this total amount was transferred from Germany. The Ghanaian diaspora has a few organized communities in Germany. Those intend connecting and supporting co-ethnics as well as preserving Ghanaian culture.

The migration relation between Ghana and Germany has recently experienced a climax. Due to the economic growth in Ghana, Ghana has now joined in the trend of receiving returnees. In 2011, Ghana's annual economic growth rate marked 15\%, which is even higher than China's (Harding, 2012). Motives for returning back to Ghana are not only to "seize opportunities from booming economy" (Hirsch, 2012), but also the intention to support the COO with the acquired skills as returning experts (cf. Ammassari, 2004; Avle, 2014). The significance of returnee entrepreneurs has also been recognized by policymakers in Ghana. The Ghanaian government collaborates with the German government to support the knowledge transfer back to Ghana in official projects (CIM-Centre for International Migration and Development, 2015).

\section{Data Collection and Interpretation}

\section{Entrepreneur A - Ghanaian Diaspora Entrepreneur in Germany}

Entrepreneur A is 54 years old and emigrated from Ghana to Germany in 1985 at the age of 24 due to the political turmoil in his home country. He finished his high school with the focus on economics in Ghana. In 1990, he started working in an automobile factory and became shift foreman soon after. Due to his responsibilities and labor-intensive daily work, entrepreneur A decided to become an entrepreneur. In the first three years, he was preparing for the establishment of his own cleaning company, while he still worked as a full-time employee of the factory. In 2003, he registered his company at the local chamber of commerce in Eastern Germany together with his wife. His company had 13 employees at the time the interview was conducted. The maximum number of employees was about 40 when the business was most successful.

Entrepreneur A already accumulated human capital resting on high-school education in Ghana and 17 years of work experience in Germany including management experience as shift foreman in the factory before he started his own business. His business was strongly backed up by his family and close friends in Germany who supported him both emotionally and practically. For instance, entrepreneur A's son developed a design for his business cards. His Ghanaian wife and daughter emotionally supported him. His German close friends played significant roles as well by offering advice and ideas for his business. Entrepreneur A also had certain connections with former colleagues, friends and acquaintances. This network can be described as weak ties, as he did not interact with them on a regular basis. These people sometimes provided business opportunities through recommendations. Besides that, entrepreneur A had a broad client network, some of which provided him with locations and opportunities where he could promote 
his business and seek for new business opportunities. These clients also actively recommended his business to others. Entrepreneur A perceives this network as very important to his business, since he values honesty in his business and, therefore, relies on a wordof-mouth marketing of satisfied customers.

Notably, entrepreneur $A$ is the chairman of a Ghanaian diaspora association (founded in 1994) in a city where he lives in Germany. This network aims to preserve Ghanaian culture and language and has also contacts with other Ghanaian diaspora networks all over Europe. About 100 members belong to this association. These members support each other not only on the business level, but also on the private level. There are monthly meetings where many (60-70 on average) of the members get together. Being the chairman of this network allows him to have relationships with a number of Ghanaian diasporans in the region. Entrepreneur A hired several people from this network, who were seeking for a job. Entrepreneur A has relations with Ghanaian diasporans in other European countries such as France and the Netherlands, since there are meetings for Ghanaian diaspora associations from different countries. Such meetings with Ghanaian diasporans in Europe energize and motivate him to conduct his business further.

His network in Ghana is limited only to informal contacts with his family and friends. Entrepreneur A described that they did not have any impact on his business in Germany, even though he regularly visits them in Ghana. Only very close friends know what Entrepreneur $A$ is doing in Germany.

\section{Entrepreneur B - Ghanaian Returnee Entrepreneur Back in Ghana}

Entrepreneur B is 53 years old and immigrated to Germany in 1984 after finishing his lower secondary education and working as a repairman in Ghana. Entrepreneur B chose Germany as he got a job offer from his relative to work in his restaurant. In 1987, entrepreneur B started working for a shipyard company. Since then, he had worked there for 20 years until the company went bankrupt. The bankruptcy of this firm was a turning point in his life. Actually, Entrepreneur B has supported his mother's business in Ghana with his knowledge and tried in vain to establish an export business to Ghana - before he started his current business. In other words, he gathered somehow entrepreneurial experience while he was working for the shipyard company in Germany. Then he recognized a business opportunity through a conversation with a former co-worker, which made him decide to return to Ghana to start his own business.

After returning back to Ghana, he took over a bakery of his mother and started radically re-organizing her business. He knew the business well, as he had already been supporting his mother with his knowledge from Germany. He renovated workflows and restructured the value-added process by providing new machines. This change enabled an innovation to an old small bakery. The company was registered in 2007, under entrepreneur B's name. Currently, 15 employees are working for his company. This company is not a family firm, since Entrepreneur B was the only one within his family who was involved in business and invested substantial amount of money. His siblings are not involved in this business. His 82-year-old mother emotionally supports him.

Lower secondary school education, 20 years of work experience in Germany and industry-specific experience by learning from his mother in his early age built up Entrepreneur B's human capital, which is accompanied by his social capital. Entrepreneur B does not have many close friends both in Ghana and in Germany. He has two to three close 
friends in each country with whom he can share any of his problems. In Germany, entrepreneur B has an intensive network with his family (including his German wife). These strong ties supported him emotionally and also practically in his business, as they help him on both private and business levels whenever he has problems. Moreover, entrepreneur B has not actively participated in any co-ethnic networks.

Currently, entrepreneur $B$ is in a difficult situation. He is pulled in two different directions: one from Ghana by his elderly mother and the other is from Germany - from his German wife who does not consider moving to Ghana in any case and does not support his return to his COO. The current solution for this problematic situation is that entrepreneur B spends a year working in Ghana and then visits Germany for two months to see his wife and then returns again to Ghana for a year.

Entrepreneur B described his former colleagues and friends as weak ties who do not have influence on his venture, but taught him work practices and wisdom, which indirectly influenced the way he manages his business. In particular, values of 'German' punctuality, cooperativeness and accuracy that he learned from Germany, distinguish his company from other local Ghanaian firms in a positive manner, which is described as 'social remittances' in the literature (Levitt, 1998). His core Ghanaian network is with his mother, who supports him emotionally with her knowledge and labor. He also has an access to formal networks such as customers, employees and retailers. Some steady customers build a weak tie of his network and indirectly support his business with their feedback to improve his goods. His employees are trained to work with German standards and qualities such as punctuality and cooperativeness, which make them core resource of his company. His employees seemed to play a significant role in his business with their know-how and skills. Interestingly enough, Entrepreneur B also receives motivational support from retailers, who always admire the way he is managing his business. Entrepreneur B also still knows many people in Ghana, among them also some other returnees, but he describes them as acquaintances who have no influence on his venture.

Entrepreneur B is not a person who proactively establishes networks. He believes in his own personal ability and does not invest much time and efforts in establishing and maintaining networks unlike entrepreneur $A$.

\section{Network Benefits for Diaspora and Returnee Entrepreneurs}

Based on our discussion on network dynamics of diaspora and returnee entrepreneurs depicted in Figure 1 and Figure 2, findings are systematically analyzed in line with six main benefits from networks discussed in the previous section: (i) access to information and knowledge; (ii) access to customers and suppliers; (iii) reputation; (iv) access to low cost labor; (vi) emotional and motivational support.

Entrepreneur A, a Ghanaian diaspora entrepreneur, has an access to three different types of networks in Germany: (i) formal networks; (ii) informal networks; (iii) diaspora network. First, the formal network of entrepreneur A with former colleagues and clients is described as weak. However, this network offers significant support. Former colleagues and current clients support his business by giving him opportunities and locations to advertise his business. Entrepreneur A heavily relies on a word-of-mouth marketing to acquire new clients, which helped establishing a good reputation of his business. 
The informal network of entrepreneur A in the COR consists of his Ghanaian wife and children as well as of a few close German friends. They support entrepreneur A both emotionally and practically. He shares problems in his business with them and asks them for advice. For instance, his son helped his business on an operational level by designing his business card. Through this informal network in the COR, entrepreneur A has an access to tacit knowledge and expertise required to conduct his business.

Entrepreneur A's network is characterized by close connection to Ghanaian diaspora networks in Germany and in Europe. As a representative of a regional Ghanaian diaspora association, he is in regular contact with a number of Ghanaian diasporans living in his city. Moreover, he meets Ghanaian diasporans in neighboring countries at supra-regional diaspora meetings. Regular meetings with co-ethnics provide him with energy and motivation to make his business successful and to become a role model for Ghanaian diasporans in Germany. This network gives him also access to co-ethnic labor. In fact, he hired several co-ethnics from this network. However, the case does not indicate that the motivation to hire co-ethnics from the diaspora network is wage-related (Chrysostome \& Arcand, 2009). His primary motivation to hire them is to help them find a job. Co-ethnic employees have advantages in contrast with local employees, since "authority can be secured on the basis of personal loyalties and ethnic allegiance" (Aldrich, Waldinger \& Ward,1990b: 38).

While it has been 30 years since he left Ghana, he still has regular contacts with his family and close friends. Entrepreneur A visits them on a regular basis. In line with the findings by Farquharson and Pruthi (2015), entrepreneur A has lost his weak ties in the COO due to his absence for 30 years. When sharing problems connected with his business, entrepreneur $A$ feels strong emotional support from this network that maintains his motivation to continue his business. The network benefits of entrepreneur $A$ are summarized in Figure 3.

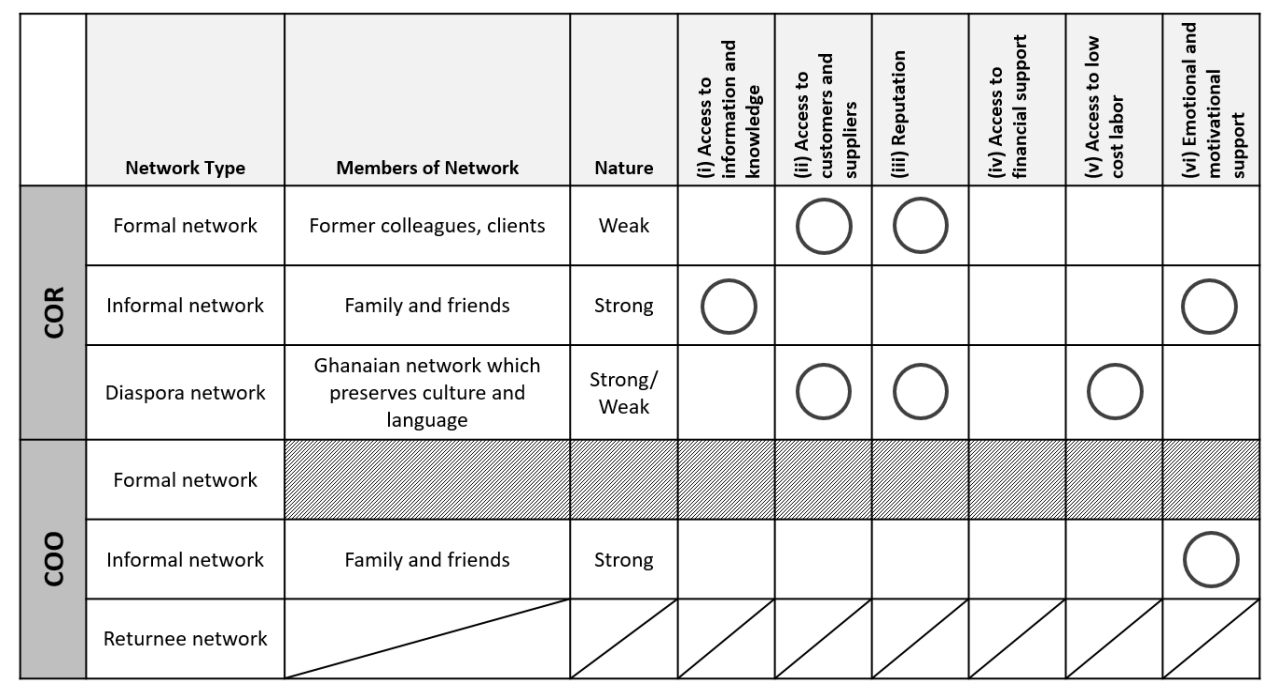

Figure 3. Network Benefits for Entrepreneur A (Diaspora Entrepreneur) Source: own elaboration. 
Unlike entrepreneur A, entrepreneur B as a Ghanaian returnee entrepreneur does not have extensive networks in the COR. Even though he worked at a German company for more than 20 years, formal networks with his previous colleagues do not play any significant role in his business. This may be explained by the nature of his business. Entrepreneur B conducts his business for Ghanaian people in Ghana. Therefore, German colleagues and acquaintances could not possibly support his business mostly due to the geographical distance. Since formal networks with his former colleagues were based on weak ties, he could not maintain these relationships after he decided to return to Ghana.

Entrepreneur B has strong ties with his German wife and children as well as a few close German friends in the COR. He visits Germany to maintain these relationships for two months a year. While they offer emotional and motivational support to entrepreneur B to a certain extent, his German wife does not fully support his business activities due to his long absence.

Entrepreneur B's networks in the $\mathrm{COO}$, both formal and informal, have strong influence on his business activities. Unlike our anticipations, he is not in regular contact with other returnees. Therefore, the case does not support the role of returnee networks in the COO. As for formal networks, he has relations with customers, employees and retailers. His customers provide him with insightful feedback information on his products. Retailers play also a significant role in his business. Since they are convinced of the quality of his products and his way of doing business, they recommended his products to other people and maintain his entrepreneurial motivation by their complements. His COO informal network consists of his family, especially his mother, who supports him both emotionally and practically with her industrial knowledge and know-how based on many years of experience in the same sector. Network benefits for entrepreneur $B$ are summarized in Figure 4.

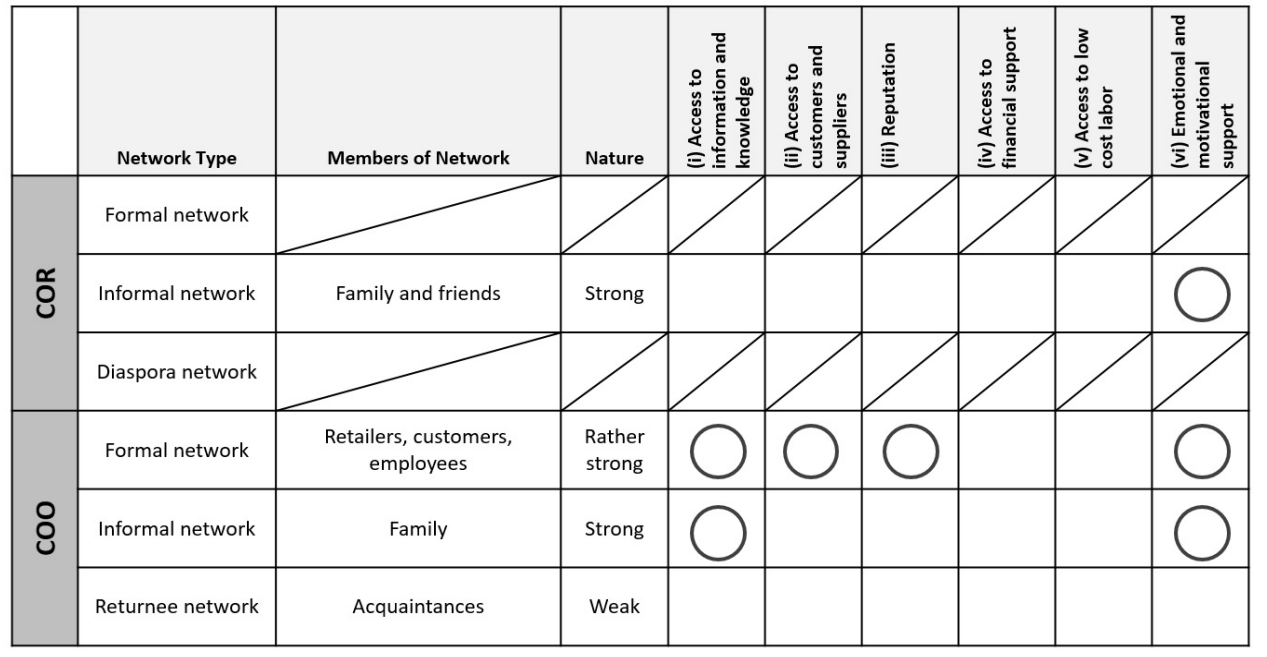

Figure 4. Network Benefits for Entrepreneur B

Source: own elaboration. 


\section{RESULTS AND DISCUSSION}

The case studies highlight several novel aspects of network benefits in the context of diaspora and returnee entrepreneurship.

First of all, two cases highlight the impact of degree of embeddedness on entrepreneurs' networks. Entrepreneur A has benefits mainly from his COR network and entrepreneur $B$ from his $\mathrm{COO}$ network. While there is a general assumption that diaspora and returnee entrepreneurs may gain benefits from their mixed embeddedness (Kloosterman, van der Leun \& Rath, 1999.) which is assumed to offer diversified networks both in $\mathrm{COO}$ and $\mathrm{COR}$, little is known about how various factors influence the actual network usage of such entrepreneurs. Some of previous researchers argue that the times in which entrepreneurs are absent have an impact on available networks in the country (Wahba \& Zenou, 2011; Farquharson \& Pruthi, 2015). The findings of the case studies above are consistent with their reasoning. Entrepreneur A has lost weak ties in the $\mathrm{COO}$ due to not spending enoughtime in Ghana over many years, while entrepreneur $B$ has lost weak ties in the COR after returning back to Ghana. Despite of regular travels between COOs and CORs, a long absence from a country seems to be related to the loss of weak ties.

Another dimension which may have an impact on the network structure of diaspora and returnee entrepreneurs is the nature of business. On one side, diasporans' transnational entrepreneurial activities in the context of international trade have attracted much research attention in the previous literature (Cohen, 2008; Kyle, 1999; Sequeira, Carr \& Rasheed, 2009). The diasporans and returnees who engage in such transnational ventures may rely on networks in both the $\mathrm{COO}$ and the COR, as their business activities are closely related to actors on both sides. On the other side, entrepreneurship within ethnic enclaves has been studied as typical economic activities of diasporans (Salaff et al., 2003; Ndofor \& Priem, 2011). Those involved in enclave entrepreneurial activities have intensive networks within the enclave. Both of the two presented cases, however, can be classified neither as transnational entrepreneurship nor as ethnic enclave entrepreneurship. Entrepreneur A offers his services to the local population in the COR and entrepreneur B offers his products to the local population in the COO. Their economic activities are neither transnational nor limited to the ethnic enclave. The nature and structure of business influence the way entrepreneurs use different types of networks.

One additional point in this regard is the difficulty of maintaining networks in two different countries. Even though diaspora and returnee entrepreneurs are embedded in two different societal and cultural constellations, it does not automatically mean that they have similarly broad and strong networks in both countries. Entrepreneur B's case shows some evidence. Although a year ago he spent two months in Germany, this time was mostly used for spending time with his family and with very close friends. He did not have sufficient time to maintain relationships with others, such as weak ties like his formal networks from his previous vocation. As a result, he lost many relationships in Germany due to his transnational living style. Their physical absence from one country naturally leads to a tenuous relation with people there. This weakens the argumentation by Tung (2008) that diasporans can now easily maintain their relations despite great distance due to the technological development in transportation and communication sec- 
tors. It can be rather specific to Ghana, where digital communication is not as common as in Western countries.

One of other significant similarities between diaspora and returnee entrepreneurs is strong emotional and motivational support by informal networks. They receive strong emotional support from their family and close friends in both the COO and COR. Family ties are often strong ties by nature. Therefore, they will not be lost despite of diasporans' physical absence. One exception is the situation, entrepreneur B faced when his entrepreneurial activities as returnee in Ghana were not supported by his German wife. This situation reveals a dimension which has not been considered in the previous research on diaspora and returnee entrepreneurship. Previous studies have highlighted strong support from families for entrepreneurial activities by diasporans and returnees. This assumption may be correct when they are married within the same ethnic group. However, this looks different in case of international and interethnic marriages. Family members can be unsupportive when they are not flexible in terms of locations. In a similar vein, some studies suggest that second- or third-generation immigrants have a reluctance to connect themselves to their homeland, which could cause inflexibility of location choice. As international marriages increase and the number of diaspora and returnees whose spouses have other ethnic backgrounds also increases, it is necessary to consider the influence of locational inflexibility of entrepreneurs and their family members on diaspora and returnee entrepreneurship in future research.

Moreover, entrepreneur A and entrepreneur B have a commonality that they both do not use their network as a means of accessing financial resources. Both interviewees operate their business in rather simple constellations where large amounts of seed or earlier stage capitals are not required. As discussed in the previous chapter, prior literature predominantly focused on the economic contribution of high-skilled diasporans and returnees (Filatotchev et al., 2009; Wang, Zweig \& Lin, 2011). Therefore, networks have been seen as a potentially important financial source. Both entrepreneur A and B are not high-skilled diasporans and their businesses are also not related to technologies. It may indicate that diasporan's educational background as well as the technology orientation of his or her business have impact on their intention to use networks for financial source.

Both cases highlight the impact of mixed embeddedness (Kloosterman, van der Leun $\&$ Rath, 1999) on entrepreneurial activities of both diaspora and returnee entrepreneurs. While the mixed embeddedness does not necessarily facilitate networks in both of the two countries due to the difficulty in maintaining geographically distanced networks, both of the interviewees showed their unique individual human capitals as essential factors for their business (Black, King \& Tiemoko, 2003). Entrepreneur A's sincere efforts to maintain Ghanaian culture and language as a chairman of Ghanaian diaspora network in Germany moved network members to help his business to a large extent. Entrepreneur B has learnt punctuality and hardwork when he worked in Germany. He trained his local employees to be punctual and thrive on high-quality of products, which won the trust of retailers and suppliers who supported him in different manners. Through living in a totally different context from $\mathrm{COO}$, diasporans may develop their individual human capitals. The above cases show that this human capital is a requirement for them to make effective use of networks. 


\section{CONCLUSIONS}

This paper investigates how diaspora and returnee entrepreneurs use their networks in $\mathrm{COO}$ and COR. In order to answer the research questions, one case study with Ghanaian diaspora entrepreneur in Germany and the other with Ghanaian returnee entrepreneur from Germany were conducted by focusing on network benefits. We intentionally selected entrepreneurs who are not high-skilled migrants and who do not conduct their business in the high-tech industry so that this paper can extend previous literature on returnee entrepreneurship, which overemphasized such specific types of migrants.

This paper offers first implications of network benefits for diaspora and returnee entrepreneurs. The case findings show that diaspora and returnee entrepreneurs may rely on networks in $\mathrm{COO}$ and COR with different degrees of intensity. This difference may be caused by the structure of business and the absence/presence of entrepreneurs from/in the country. First, diaspora entrepreneurs whose business has no transnational dimension, networks in the country where they conduct business are more significant than the ones in the other country. Second, physical absence from a certain country may lead to the severance of some relations. Also, we found out that family members are not necessarily supportive of diasporans' entrepreneurial activities in case of international marriage.

We are aware of limitations of this paper. First, two cases are rather not sufficient to conduct a comparative study to find certain patterns. Therefore, this paper could not reduce the bias of investigators. In future research, more case studies should be conducted to consider additional dimensions such as educational backgrounds and industrial variations. In the long run, qualitative approaches should be conducted to take a first step to generalize findings. Second, time dimension is not considered for this study. Entrepreneurship is a process (Santarelli \& Vivarelli, 2007), which consists of different time dimensions. Entrepreneurs may gain benefits from different types of networks in different phases (Birley, 1986).

Despite these limitations, this study makes some contributions to the current state of research. First, we bring new insights to returnee entrepreneurship literature by focusing on an ethnic group different from the main previous research which has predominantly focused on Chinese, Taiwanese and Indian diasporans. Second, investigating entrepreneurial activities by migrants who are not highly skilled highlights the significance of their economic activities, which has been overlooked by previous research. In fact, our case studies show that a Ghanaian returnee entrepreneur became successful in his business back home through transferring knowledge, culture and institutions from Germany ('social remittance'). This action changed working attitudes of his employees and the way he does business is acknowledged by local business partners. Third, this study tackles the heterogeneity within diaspora entrepreneurship. Diaspora entrepreneurship consists of sub-divided types including returnee entrepreneurs, transnational entrepreneurs and ethnic entrepreneurs (Drori, Honig \& Wright, 2009). However, previous studies have mostly compared diaspora entrepreneurs with local ones and did not attempt to explore the differences between sub-categories of diaspora entrepreneurs. This study compares a diaspora entrepreneur and a returnee entrepreneur to see how they are similar and different from each other. 
Based on the current situation and our findings, we suggest that future research shed more light on the diversity within diaspora entrepreneurship in order to develop more understanding on the micro-level. Additionally, cross-country studies are a meaningful method to consider country variation, as the phenomenon of diaspora and returnee entrepreneurship is deeply embedded in COR and COR.

\section{REFERENCES}

Aldrich, H. E., \& Cliff, J. E. (2003). The pervasive effects of family on entrepreneurship: Toward a family embeddedness perspective. Journal of Business Venturing, 18(5), 573-596.

Aldrich, H. E., Waldinger, R., \& Ward, R. (1990a). Ethnicity and entrepreneurship. Annual Review of Sociology, 16, 111-135.

Aldrich, H., Waldinger, R. \&Ward, R. (1990b). Ethnic entrepreneurs. California, Sage Publication.

Aldrich, H. E., \& Zimmer, C. (1986). Entrepreneurship Through Social Networks. University of Illinois at Urbana-Champaign's Academy for Entrepreneurial Leadership Historical Research Reference in Entrepreneurship. Available at SSRN: http://ssrn.com/abstract=1497761

Aliaga-Isla, R., \& Rialp, A. (2012). How Do Informatio and Experience Play a Role in the Discovery of Entrepreneurial Opportunitites? The Case of Latin-American Immigrants in Barcelona. Latin American Business Review, 13(1), 59-80.

Altinay, L., \& Altinay, E. (2008). Factors influencing business growth: the rise of Turkish entrepreneurship in the UK. International Journal of Entrepreneurial Behavior \& Research, 14(1), 24-46.

Ammassari, S. (2004). From nation-building to entrepreneurship: the impact of élite return migrants in Côte d'Ivoire and Ghana. Population, Space and Place, 10(2), 133-154.

Arenius, P., \& De Clercq, D. (2005). A network-based approach on opportunity recognition. Small Business Economics, 24(3), 249-265.

Auster, E., \& Aldrich, H. (1984). Small business vulnerability, ethnic enclaves and ethnic enterprise. In R. Ward \& R. Jenkins (Eds.), Ethnic communities in business. Strategies for economic survival (pp. 39-54). Cambridge: Cambridge University Press.

Avle, S. (2014). Articulating and Enacting Development: Skilled Returnees in Ghana's ICT Industry. Information Technologies \& International Development, 10(4), 1-13.

Barrett, G. A., Jones, T. P., \& McEvoy, D. (1996). Ethnic minority business: Theoretical discourse in Britain and North America. Urban studies, 33(4-5), 783-809.

Basu, A., \& Goswami, A. (1999). South Asian entrepreneurship in Great Britain: factors influencing growth. International Journal of Entrepreneurial Behavior \& Research, 5(5), 251-275.

Bhagwati, J., \& Hamada K. (1974). The brain drain, international integration of markets for professionals and unemployment: a theoretical analysis. Journal of Development Economics, 1(1), 19-42.

Birley, S. (1986). The role of networks in the entrepreneurial process. Journal of Business Venturing, 1(1), 107-117.

Black, R., \& Castaldo, A. (2009). Return migration and entrepreneurship in Ghana and Cote d'Ivoire: The role of capital transfers. Tijdschrift voor economische en sociale geografie, 100(1), 44-58.

Black, R., King, R., \& Tiemoko, R. (2003). Migration, return and small enterprise development in Ghana: A route out of poverty?. In International Workshop on Migration and Poverty in West Africa, University of Sussex, United Kingdom (Vol. 13). 
Bosma, N., Hessels, J., Schutjens, V., Van Praag, M., \& Verheul, I. (2012). Entrepreneurship and role models. Journal of Economic Psychology, 33(2), 410-424.

Brown, B., \& Butler, J. E. (1993). Networks and entrepreneurial development: the shadow of borders. Entrepreneurship \& Regional Development, 5(2), 101-116.

Brubaker, R. (2005). The 'diaspora' diaspora. Ethnic and Racial Studies, 28 (1), 1-19.

Brüderl, J., \& Preisendörfer, P. (1998). Network support and the success of a newly founded business. Small Business Economics, 10, 213-225.

Burt, R. (1992). Structural Holes: The Social Structure of Competition. Cambridge: Harvard University Press.

CIM Centre for International Migration and Development (2015) a joint operation of GIZ and the German Federal Employment Agency. Ghana. Retrieved on February 20, 2015, from http://www.cimonline.de/de/weltweit/192.asp

Cohen, R. (2008). Global Diasporas. An Introduction. 2nd ed. London: Routledge.

Coleman, J. (1990). Foundations of social theory. MA, Cambridge: The Belknap Press of Harvard University Press.

Cooper, A. C., \& Yin, X. (2005). Entrepreneurial networks. In M. A. Hitt \& R. D. Ireland (Eds), The Blackwell encyclopaedia of entrepreneurship (pp. 98-100). Oxford: Blackwell Publishing.

Chen, W., \& Tan, J. (2009). Understanding Transnational Entrepreneurship Through a Network Lens: Theoretical and Methodological Considerations. Entrepreneurship Theory and Practice, 33(5), 1079-1091.

Chrysostome, E. (2010). The success factors of necessity immigrant entrepreneurs: In search of a model. Thunderbird International Business Review, 52(2), 137-152.

Chrysostome, E., \& Arcand, S. (2009). Survival of necessity immigrant entrepreneurs: An exploratory study. Journal of Comparative International Management, 12(2), 3-29.

Clark, K., \& Drinkwater, S. (2010). Recent trends in minority ethnic entrepreneurship in Britain. International Small Business Journal, 28(2), 136-146.

Clydesdale, G. (2008). Business immigrants and the entrepreneurial nexus. Journal of International Entrepreneurship, 6(3), 123-142.

Dai, O., \& Liu, X. (2009). Returnee entrepreneurs and firm performance in Chinese high-technology industries. International Business Review, 18(4), 373-386.

Davidsson, P., \& Honig, B. (2003). The role of social and human capital among nascent entrepreneurs. Journal of Business Venturing, 19, 301-331.

Denzin, N. (1970).The Research Act in Sociology. Chicago: Aldine.

Drori, I., Honig, B., \& Wright, M. (2009). Transnational entrepreneurship. An emergent field of study. Entrepreneurship Theory and Practice, 33(5), 1001-1022.

Dustmann, C., \& Weiss, Y. (2007). Return migration: theory and empirical evidence from the UK. British Journal of Industrial Relations, 45(2), 236-256.

Eisenhardt, K. M. (1989). Building theories from case study research. Academy of Management Review, 14(4), 532-550.

Elo, M. (2014). Diaspora networks in international business and transnational entrepreneurship-A literature review. Zentra Working Paper in Transnational Studies, 40, 1-18.

Elo, M., \& Freiling, J. (2015). Transnational Entrepreneurship. American Journal of Entrepreneurship, 8(2), forthcoming.

Evans, M. D. R. (1989). Immigrant entrepreneurship: Effects of ethnic market size and isolated labor pool. American Sociological Review, 54(6), 950-962. 
Farquharson, M., \& Pruthi, S. (2015). Returnee Entrepreneurs: Bridging Network Gaps in China after Absence [dagger]. South Asian Journal of Management, 22(2), 9.

Federal Ministry for Economic Cooperation and Development (2009). The Ghanaian diaspora in Germany-Its contribution to development in Ghana economic development and employment division, 7-44.

Freeman, R. E. (1999). Divergent stakeholder theory. Academy of Management Review, 24(2), 233236.

Filatotchev, I., Liu, X., Buck, T., \& Wright, M. (2009). The export orientation and export performance of high-technology SMEs in emerging markets: The effects of knowledge transfer by returnee entrepreneurs. Journal of International Business Studies, 40(6), 1005-1021.

Gimeno, J., Folta, T. B., Cooper, A. C., \& Woo, C. Y. (1997). Survival of the fittest? Entrepreneurial human capital and the persistence of underperforming firms. Administrative Science Quarterly, 42(4); 750-783.

Granovetter, M. S. (1973). The strength of weak ties. American Journal of Sociology, 78, 1360-1380.

Gillespie, K., Riddle, L., Sayre, E., \& Sturges, D. (1999). Diaspora interest in homeland investment. Journal of International Business Studies, 30(3), 623-634.

Harding, C. (2012). Ghana and Nigeria among world's fastest growing economies in 2012/2013. How we made in Africa-Insight into business in Retrieved on February 28, 2015, from Africahttp://www.howwemadeitinafrica.com/ghanaand-nigeria-among-worlds-fastest-growingeconomies-in-20122013/16062/

Harima, A. (2014). Network Dynamics of Descending Diaspora Entrepreneurship: Multiple Case Studies with Japanese Entrepreneurs in Emerging Economies. Journal of Entrepreneurship, Management and Innovation, 10(4), 65-92.

Hayek, F.A. von (1967). The Theory of Complex Phenomena. In Hayek, F.A. von (Ed.), Studies in Philosophy, Politics and Economics (22-42). London, UK: Routledge \& Kegan Paul.

Hirsch, A. (2012). Ghana - The booming world-Ghana expatriates return home to seize opportunities from booming economy. Theguardian. Retrieved on February 28, 2015, from http://www. theguardian.com/world/2012/dec/19/ghana-expatriates-return-home-economy

Hoang, H., \& Antoncic, B. (2003). Network-based research in entrepreneurship - A critical review. Journal of Business Venturing, 18, 165-187

Hoang, H., \& Yi, A. (2015). Network-based Research in Entrepreneurship: A Decade in Review. Foundations and Trends in Entrepreneurship, 11(1), 1-54.

Hoang, H., \& Gimeno, J. (2010). Becoming a founder: How founder role identity affects entrepreneurial transitions and persistence in founding. Journal of Business Venturing, 25(1), 41-53.

Johannisson, B. (1990). Economies of overview-guiding the external growth of small firms. International Small Business Journal, 9(1), 32-44.

Kenney, M., Breznitz, D., \& Murphree, M. (2013). Coming back home after the sun rises: Returnee entrepreneurs and growth of high tech industries. Research Policy, 42(2), 391-407.

Kloosterman, R., van der Leun, J., \& Rath, J. (1999). Mixed embeddedness. (In)formal Economic Activities and Immigrant Business in the Netherlands. International Journal of Urban and Regional Research, 23(2), 253-267.

Kloosterman, R., \& Rath, J. (2002). Working on the Fringes: Immigrant Businesses, Economic Integration and Informal Practices. Marginalisering eller Integration. Stockholm: NUTEK.

Kyle, D. (1999). The Otavalo trade diaspora: social capital and transnational entrepreneurship. Ethnic and Racial Studies, 22(2), 422-446. 
Kuznetsov, Y. (2006).Diaspora Networks and the International Migration of Skills. How Countries Can Draw on Their Talent Abroad. Washington DC: World Bank Publications (WBI Development Studies).

Landolt, P., Autler, L., \& Baires, S. (1999). From hermano lejano to hermano mayor: The dialectics of Salvadoran transnationalism. Ethnic and Racial Studies, 22(2), 290-315.

Lervik, J.E.B. (2011). The single MNC as a research site. In Piekkari, R. \& Welch, C. (Eds.), Rethinking the Case Study in International Business and Management Research (pp. 229-250). Cheltenham: E. Elgar.

Levitt, P. (1998). Social remittances: Migration driven local-level forms of cultural diffusion. International Migration Review, 926-948.

Light, I. (1984). Immigrant and ethnic enterprise in North America. Ethnic and Racial Studies, 7(2), 195-216.

Light, I., Bhachu, P., \& Karageorgis, S. (1993). Migration networks and immigrant entrepreneurship. In I. Light \& P. Bhachu (Eds.). Immigration and entrepreneurship: Culture, capital, and ethnic networks (pp. 25-50).

Liu, X., Lu, J., Filatotchev, I., Buck, T., \& Wright, M. (2010). Returnee entrepreneurs, knowledge spillovers and innovation in high-tech firms in emerging economies. Journal of International Business Studies, 41(7), 1183-1197.

Mustafa, M., \& Chen, S. (2010). The strength of family networks in transnational immigrant entrepreneurship. Thunderbird International Business Review, 52(2), 97-106.

Murphy, R. (1999). Return migrant entrepreneurs and economic diversification in two counties in south Jiangxi, China. Journal of International Development, 11(4), 661-672.

Newland, K. (2009). Circular Migration and Human Development. Human Development Research Paper (HDRP) Series, Vol. 42, No. 2009.

Ndofor, H. A., \& Priem, R. L. (2011). Immigrant entrepreneurs, the ethnic enclave strategy and venture performance. Journal of Management, 37(3), 790-818.

Nielsen, T. M., \& Riddle, L. (2009). Investing in peace: The motivational dynamics of diaspora investment in post-conflict economies. Journal of Business Ethics, 89(4), 435-448.

Nieswand, B. (2009). Development and diaspora: Ghana and its migrants. Sociologus, 59(1), 17-31.

Nicolaou, N., \& Birley, S. (2003). Social networks in organizational emergence: The university spinout phenomenon. Management Science, 49(12), 1702-1725.

Nkongolo-Bakenda, J.-M., \& Chrysostome, E. V. (2013). Engaging Diasporas as International Entrepreneurs in Developing Countries: In Search of Determinants. Journal of International Entrepreneurship, 11(1), 30-64.

O'Donnell, A., Gilmore, A., Cummins, D., \& Carson, D. (2001). The network construct in entrepreneurship research: a review and critique. Management Decision, 39(9), 749-760.

Ozgen, E., \& Baron, R. A. (2007). Social sources of information in opportunity recognition: Effects of mentors, industry networks, and professional forums. Journal of Business Venturing, 22(2), 174-192.

Piperopoulos, P. (2010). Ethnic minority businesses and immigrant entrepreneurship in Greece. Journal of Small Business and Enterprise Development, 17(1), 139-158.

Portes, A., Guarnizo, L. E., \& Haller, W. J. (2002). Transnational Entrepreneurs: An Alternative Form of Immigrant Economic Adaption. American Sociological Review, 67(2), 278-298.

Rath, J., \& Kloosterman, R. (2000). Outsiders' business: A critical review of research on immigrant entrepreneurship. International Migration Review, 657-681. 
Riddle, L. (2008). Diaspora. Exploring their Development Potential. ESR Review, 10(2), 28-36.

Riddle, L., Hrivnak, G. A., \& Nielsen, T. M. (2010). Transnational diaspora entrepreneurship in emerging markets: Bridging institutional divides. Journal of International Management, 16(4), 398-411.

Riddle, L., \& Brinkerhoff, J. (2011). Diaspora Entrepreneurs as Institutional Change Agents. The Case of Thamel.com. International Business Review, 20, 670-680.

Safran, W. (1991). Diasporas in Modern Societies. Myths of Homeland and Return. Journal of Transnational Studies, 1(1), 83-99.

Salaff, J. W., Greve, A., Siu-Lun, W., \& Ping, L. X. L. (2003). Ethnic entrepreneurship, social networks, and the enclave. In Yeoh, Brenda, Charney, Michael W., Tong Chee Kiong (Eds.), Approaching Transnationalisms - Studies on transnational societies, multicultural contacts, and imaging of home (pp. 61-82). New York: Springer US.

Santarelli, E., \& Vivarelli, M. (2007). Entrepreneurship and the process of firms' entry, survival and growth. Industrial and Corporate Change, 16(3), 455-488.

Saxenian, A. (2002). Transnational communities and the evolution of global production networks: the cases of Taiwan, China and India. Industry and Innovation, 9(3), 183-202.

Saxenian A. (2005). From brain drain to brain circulation: Transnational communities and regional upgrading in India and China. Studies in Comparative International Development, 40(2), 35-61.

Seidman, I. (2006). Interviewing as Qualitative Research-A Guide for Researchers in Education and the Social Science. 3rd ed., New York: Teachers College Press.

Sequeira, J. M., Carr, J. C., \& Rasheed, A. A. (2009). Transnational entrepreneurship: determinants of firm type and owner attributions of success. Entrepreneurship Theory and Practice, 33(5), 1023-1044.

Shane, S., \& Cable, D. (2002). Network ties, reputation, and the financing of new ventures. Management Science, 48(3), 364-381.

Sheffer, G. (2003): Diaspora Politics. At Home Abroad. Cambridge, Mass: Cambridge University Press.

Sheffer G. (1986). Modern diasporas in international politics. New York: St. Martin's.

Slotte-Kock, S., \& Coviello, N. (2010). Entrepreneurship research on network processes: a review and ways forward. Entrepreneurship Theory and Practice, 34(1), 31-57.

Smans, M., Freeman, S., \& Thomas, J. (2014). Immigrant entrepreneurs: The identification of foreign market opportunities. International Migration, 52(4), 144-156

Starke, R. E. (2010). Qualitative Research. Studying how things work. Ney Work: Guilford.

Statistisches Bundesamt. (2013). Retrieved on March 05, 2015, from http://de.statista.com/statistik/daten/studie/1221/umfrage/anzahl-der-auslaender-indeutschland-nach-herkunftsland/

Tung, R. L. (2008). Brain circulation, diaspora, and international competitiveness. European Management Journal, 26(5), 298-304.

Uzzi, B. (1996). The sources and consequences of embeddedness for the economic performance of organizations: The network effect. American Sociological Review, 61, 674-698.

Vanhonacker, W., Zweig, D., \& Chung, S. F. (2005). Transnational or social capital? Returnee versus local Entrepreneurs. Center on China's Transnational Relations Working Paper, 7, 1-28.

Vasileva, K. (2011). 6.5\% of the EU population are foreigners and $9.4 \%$ are born abroad. Eurostat Statistics in Focus 34/2011. Publication Office of the European Union. Luxembourg. 
Vemuri, S. R. (2014). Formation of Diaspora Entrepreneurs. ZenTra Working Papers in Transnational Studies No 41 / 2014. ZenTra - Center for Transnational Studies.

Venturini, A. (2008). Circular migration as an employment strategy for Mediterranean countries. CARIM/RSCAS ASN, 39, 1-14.

Volery, T. (2007). Ethnic entrepreneurship: a theoretical framework. Handbook of Research on Ethnic Minority Entrepreneurship, 1, 30-41.

Wadhwa, V., Jain, S., Saxenian, A., Gereffi, G., \& Wang, H. (2011). The Grass is Indeed Greener in India and China for Returnee Entrepreneurs: America's New Immigrant Entrepreneurs-Part VI. Available at SSRN 1824670.

Wahba, J., \& Zenou, Y. (2012). Out of Sight, Out of Mind. Migration, Entrepreneurship and Social Capital. Regional Science and Urban Economics, 42(5), 890-903.

Waldinger, R., Aldrich, H., \& Ward, R. (1990). Opportunities, group characteristics, and strategies. In R. Waldinger, H. Aldrich \& R. Ward (Eds.), Ethnic entrepreneurs: Immigrant business in industrial societies. Newbury Park, CA: Sage Publication.

Wang, H., Zweig, D., \& Lin, X. (2011). Returnee Entrepreneurs: Impact on China's globalization process. Journal of Contemporary China, 20(70), 413-431.

Westwood, M. J., Mak, A., Barker, M., \& Ishiyama, F. I. (2000). Group procedures and applications for developing sociocultural competencies among immigrants. International Journal for the Advancement of Counselling, 22(4), 317-330.

World Bank (2014). Migration and Remittances: Recent Developments and Out-look. Special Topic: Forced Migration. Migration and Development Brief, 23, 1-2 Retrieved on February 19, 2015, from http://siteresources.worldbank.org/INTPROSPECTS/Resources/3349341288990760745/ MigrationandDevelopmentBrief23.pdf

Wright, M., Liu, X., Buck, T., \& Filatotchev, I. (2008). Returnee Entrepreneurs, Science Park Location Choice and Performance: An Analysis of High-Technology SMEs in China. Entrepreneurship Theory and Practice, 32(1), 131-155.

Yin, R. K. (2013). Case Study Research: Design and Methods. Los Angeles: Sage Publications.

Zaheer, S. (1995). Overcoming the liability of foreignness. The Academy of Management Journal, 38 (2), 341-363.

Zhao, Y. (2002). Causes and consequences of return migration: recent evidence from China. Journal of Comparative Economics, 30(2), 376-394.

Zhou, M. (2004). Revisiting Ethnic Entrepreneurship: Convergencies, Controversies, and Conceptual Advancements. International Migration Review, 38(3), 1040-1074.

Zimmer, C., \& Aldrich, H. (1987). Resource Mobilization through Ethnic Networks Kinship and Friendship Ties of Shopkeepers in England. Sociological Perspectives, 30(4), 422-445.

Zhou, M., \& Liu, H. (2015). Transnational Entrepreneurship and Immigrant Integration: New Chinese Immigrants in Singapore and the United States. Immigration and Work (Research in the Sociology of Work, Volume 27) Emerald Group Publishing Limited, 27, 169-201. 


\section{Authors}

S.D. Mayer was responsible for collecting empirical data and developing initial conceptual framework, while A. Harima and J. Freiling made contributions to further development of conceptual framework as well as interpreting collected data.

\section{Sharon Doreen Mayer}

Bachelor of Business Administration (University of Bremen, Germany).

\section{Aki Harima}

Bachelor of Business Administration (Kobe University, Japan); Master in Management (University of Mannheim, Germany); PhD candidate and research assistant at the Chair in Small Business \& Entrepreneurship (LEMEX), Faculty in Business Studies \& Economics (University of Bremen, Germany).

\section{Jörg Freiling}

Professor of the University of Bremen (Germany) and Head of the Chair in Small Business \& Entrepreneurship (LEMEX). Diploma in Business \& Economics (Ruhr University of Bochum, Germany); PhD at the Faculty of Business \& Economics (Ruhr University of Bochum); Habilitation (Ruhr University of Bochum)

\section{Correspondence to:}

Aki Harima

University of Bremen

Faculty of Business Studies and Economics,

Wilhelm-Herbst-Straße 5, 28359 Bremen, Germany

harima@uni-bremen.de

\section{Copyright and License}

This article is published under the terms of the Creative Commons Attribution - NonCommercial - NoDerivs (CC BY-NC-ND 3.0) License http://creativecommons.org/licenses/by-nc-nd/3.0/ 